\title{
IAt The Milk Goddess in Ancient Egyptian Theology
}

\section{Dr. Ayman Mohamed Ahmed Mohamed ${ }^{\bullet}$}

\section{Abstract:}

This paper tackles the question of the deity (IAt) in ancient Egyptian theology. It aims at presenting a complete overview of the deity in ancient Egyptian art and scripts in an attempt to consolidate its origin and track the forms in which it was portrayed as well as accounting for its features, symbol and role in ancient Egyptian theology since so far there has been no study tackling this deity.

The researcher attempts to provide answers for questions concerning how the name is written, differentiating the male and female forms of the deity as well as their link to divine birth and milk production. Several issues related to this deity, such as its dual nature remain vague. The abovementioned is presented in a linguistic, theological and archeological study.

\section{Keywords:}

Iat, IAt, IAty, IAtt deity, milk goddess, milk provider, Ancient Egyptian Theology.

- Lecturer of Egyptian Archaeology at the Department of Archaeology, Faculty of Arts, Damanhour University. ayman_arch@yahoo.com 


\section{Introduction}

The Ancient Egyptian creed comprised several deities who play roles in the labour process. The first of these roles is conceiving. This task was assigned to the deity Hqt (Heqet) who was responsible for the formation of the embryo and its protection inside the uterus. She also supervised the birth process. ${ }^{(1)}$ She was also the patroness of family and pregnant women. ${ }^{(2)}$ Next, comes the idea of forming the baby of which Khnum was responsible. Owing to his being a 'potter', Khnum was responsible for granting life to all creatures through his pottery wheel. ${ }^{(3)}$ Then there are the deities Taweret and Bes respectively whose roles are due after the delivery of the baby. The goddess Taweret is responsible for suckling. She is portrayed in her human form breast-feeding King Horemheb on the walls of Gebel El Silsila temple. ${ }^{(4)}$ She was associated with this role through her posture and form. She is usually portrayed in the form of a pregnant woman leaning on the protection sign $s A$. Her role was mainly protecting pregnant women. ${ }^{(5)}$

The deity Bes as well is responsible for protecting the family, pregnant women and then the children after their birth. ${ }^{(6)} \mathrm{He}$ was

(1) Wilkinson, R. H., The Complete Gods and Goddesses of Ancient Egypt, Thames \& Hudson, London, 2003, 229; Kákosy, L., "Heqet (Hqt)", LÄ 2, 1123-4; Bunson, M., Encyclopedia of Ancient Egypt, Infobase Publishing, USA, 2002, 164.

(2) Shaw, I. and Paul, N., The British Museum Dictionary of ancient Egypt, The American University in Cairo Press, The Trustees of The British Museum, 1995, 124.

(3) Wilkinson, Complete Gods and Goddesses, 194; Shaw and Paul, The British Museum Dictionary, 151.

(4) Ivanova, M., Milk in ancient Egyptian religion, Uppsala, 2009, 18.

(5) Wilkinson, Complete Gods and Goddesses, 185; Bunson, Encyclopedia of Ancient Egypt, 164, 396; Cf: Kozma, Ch., "Dwarfs in ancient Egypt", AJMG 140A, 2006, 309.

(6) Wilkinson, Complete Gods and Goddesses, 102; as for the role played by (Bes) in family and labour, his image is frequently found in labour houses during the late era, see: Shaw and Paul, The British Museum Dictionary, 54; Kozma, AJMG 140A, 309; Dzwonek, A. "Birth Houses of the Ptolemaic Period and their place in Egyptian temple building an Architectural Synthesis", 9-10, fig. 9, it is an article in:

https://www.academia.edu/7764901/Birth_Houses of Ptolemaic Period and their place i n_Egyptian_Temple_Building. An_architectural_synthesis___draft, Accessed in 8/1/2016. 
then, children's earliest protector against the evils of the outer world. ${ }^{(7)}$ His amulet was given to a pregnant woman during labour since it comprised charms to relieve the labour pain. ${ }^{(8)}$

Later, a new phase begins which is taking care of the baby and providing him with the milk needed for nourishment; a task that was assigned to several deities in ancient Egyptian faith. Isis and Hathor were deities famous for their assigned roles within this aspect. The Pyramid texts comprised a lot of amulets portraying Isis as the deity responsible for milk, especially after she had assisted in reviving Osiris. ${ }^{(9)}$ She hid her newly-born baby Horus in Delta in order to protect him against the harm his uncle Seth may inflict. She took good care of him breast-fed him as well. ${ }^{(10)}$

Likewise, there was Hesat, the cow deity, which was known as the milk deity HDt HsAt in the form of a white cow in the twelve and eighteenth Nomes. ${ }^{(12)}$ That is because, according to Faulkner, HDt HsAt means the white milk. Meanwhile, $H s A$ itself means

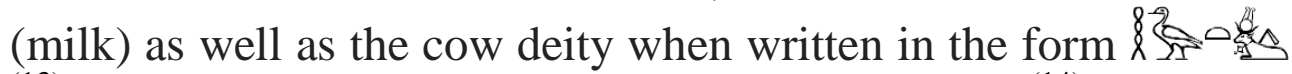
${ }^{(13)}$ as it is the deity providing mankind with milk. ${ }^{(14)}$ However,

See also: Dasen, V., Dwarfs in Ancient Egypt and Greece, Oxford, 2013, 68; Bunson,

Encyclopedia of Ancient Egypt, 70.

(7) Dzwonek, "Birth Houses", 17.

${ }^{(8)}$ Robins, G., Women in ancient Egypt, Harvard University Press, London, 1993, 83; see also: Kozma, AJMG 140A, 303, 309.

(9) King, J. K., Biosemiotics in ancient Egyptian Texts: the key unlocking the universal secret of sexuality and the birth of the limitless, Gaylord, Michigan, w.d., 280.

${ }^{(10)}$ Wilkinson, Complete Gods and Goddesses, 146.

(11) Ivanova, Milk, 3.

(12) Veiga, P., To Prevent, Treat and cure love in ancient Egypt, aspects of sexual Medicine and practice in ancient Egypt, Universidade de Lisboa, w.d., 459; for more information about Hathor as a milk goddess and Hesat-Hathor, see: Quirke, S., Exploring Religion in Ancient Egypt, ,Wiley Blackwell, Oxford, 2015, 33, 69, 172.

${ }^{(13)}$ FCD, 177; Urk. IV, 238, 14. 
the deity that is to be tackled in this study is one of the most prominent deities within this context. It was also the milk deity in Ancient Egypt that used to provide newly-born babies with milk. Hence, it was known as (milk provider). ${ }^{(15)}$ Yet, there is not enough literature about this deity to elaborate its functional roles in ancient Egyptian theology.

Milk was undoubtedly the main element in the breast-feeding process. The link between milk and deities can be traced back to earlier ages where it was offered as a form of libation to gods. ${ }^{(16)}$ It was also used to revive and reincarnate the deceased king in the afterworld as it was used to renew life through divine breastfeeding. It is also used as source of nourishment to feed the baby Horus and it was portrayed filling pots. ${ }^{(17)}$ These pots were shaped in the form of women postures. One of them even was in the form of the deity Isis breast feeding her baby Horus. Milk was poured from openings that looked like nipples. Based on the role played by Isis taking care of her baby, it was believed that these pots were partly responsible for producing milk for women who were not breast feeding. ${ }^{(18)}$ Thus, milk became a necessity for all the living as well. A lot of scenes existed portraying the process of breast feeding the monarch in Ancient Egypt mostly as a royal bay and heir as was the case with Horus.

\footnotetext{
${ }^{(14)}$ Wilkinson, Complete Gods and Goddesses, 174; in the Ptolemaic era, the deity Hesat was linked to the goddess Isis. She was portrayed as a woman with two horns of a cow like those of the cow (Isis-Hesat), ibid.

${ }^{(15)}$ Sayed Tawfic, Tārīh al-cmāra fì Miṣr al-Qadīma: LUxor, Dār al-Nahḍa al- Arbīya, 1990,201.

${ }^{(16)}$ Davidson, H. E., "Milk and the Northern Goddess", in Billington, S., (ed.), The Concept of the Goddess, Miranda Green, London, 1996, 91.

(17) Guglielmi, W., "Milchgott s. Iat", LÄ IV, 127-8; for more information about milk, its significance and its role in religious rituals as well as its association to Hathor the cow, see: Gugielmi, W., "Milk", in Redford, d., (ed.), Oxford Encyclopedia in ancient Egypt, vol. 2, Oxford, 2001, 212-3.

${ }^{(18)}$ Veiga, Treat and cure love, 458.

${ }^{(19)}$ Ivanova, Milk, 6; Milk was a symbol of renewal during religious festivals such as Sed and Opet. The goddesses offering milk to the monarch during coronation were the same
} 
Several deities, such as Hesat, Isis, Mehet-wrt and IAt (IAt) were linked to milk. All were responsible for protecting the deceased and empowering his reincarnation before the gods in the after-world. ${ }^{(20)}$ Therefore, religious texts and scenes were replete with various forms that depict the process of breast feeding such as that of the cow Hathor breast feeding the monarch $^{(21)}$ followed by several cows ready to get milked in order to feed the newly born as depicted in the Queen Hatshepsut' divine birth scene. ${ }^{(22)}$

\section{1- The Name of the Deity in Ancient Egyptian Language:}

The name of the deity IAt existed in Ancient Egyptian language in several forms since the times of the Old Kingdom. It was written in a WAs scepter in the form IA.t at the time of the Third Dynasty indicating a particular deity. ${ }^{(23)}$ Moreover, it is found in the Berlin dictionary in several forms such as: 紊, 告, IA.t indicating a particular goddess from the Old

goddesses offering milk to the deceased in the afterlife. Among the most famous goddesses that were portrayed offering milk are Hathor, Isis, Nekhbet, Nut and Wadjet. They used to offer the king milk in life and after death. Nekhbet and Wadjet were portrayed together breast feeding the baby king as well as breastfeeding the same king in the afterlife. Henceforth, both concepts were portrayed in funeral temples and scripts. For more information about the usage of milk in Opet and Sed festivals check the same reference, 811.

(20) Guglielmi, W., "Milch (wirtschaft)", LÄ IV, 125-6; According to Guglielmi, he used to make a kind of yogurt from milk. Similarly, was the idea of making butter that was known as a sort of medication made out of various animal dairies like cows and sheep herds, ibid.

${ }^{(21)}$ It has also appeared in the scene of breast feeding King Amenhotep III at the Luxor temple in the first record on the western wall of the labour chamber. The king was portrayed at the lower part breast fed by the cow Hathor; Gayet, Al., Le Temple de Louxor, MIFAO tome Quinziéme, E. Leroux, Paris, 1894, 104, pl. LXVI, fig. 185. Similarly, as the scene of Hatshepsut being breast fed by the cow Hathor in her temple at Deir Al Bahari; Gilligan, G., Comet Venus: part of the God king Scenario series, Troubador Publishing Ltd, Great Biritan, 2009, 81.

${ }^{(22)}$ Naville, E., The Temple of Deir el Bahari, Part II, offices of the Egypt exploration fund, London, 1897, fig. 53.

(23) Kahl, J, Bretschneider, M., and Kneissler, B., Frühägyptisches Wörterbuch, ErsteLieferung A-f, (HarrassowitzVerlag, Wiesbaden, 2002, 9. 
Kingdom. ${ }^{(24)}$ It is noted that the first word has taken the determinative $M w t$ and Ma'at's feather was found on top of the scepter in the other two words. This means that this word refers to a goddess.

It is also, writing the name in the phonetic form IA.t as mentioned in the Berlin dictionary indicates the $(\mathrm{t})$ preceded by a dot is used to indicate femininity, and that it is not part of the word root as it is known when changing the names into femininity in the Ancient Egyptian language. ${ }^{(25)}$ Thus, emphasizing its indication of a goddess. The other form in which the name of the deity was written was IAtt ${ }^{1}$. (26) According to Helck, this form refers to the deity in the feminine form while the form IAt refers to the masculine form as found in the scene on the Temple of Hatshepsut as will be discussed later. ${ }^{(27)}$ The Berlin dictionary indicates the appearance of the milk deity iAty without the determinative of the word since the Eighteenth Dynasty. ${ }^{(28)}$ This is highlighted also by what is stated by Hannig concerning the names of male deities in the form using the determinative of the linguistic aspect of the male form

${ }^{(24)} \mathrm{Wb} . \mathrm{I}, 26.16$.

(25) Allen, J. P., Middle Egyptian an Introduction to the Language and Culture of Hieroglyphs, Second Edition, Cambridge, 2010, 37; the word IAt in Ancient Egyptian language refers generally to a (stand) were religious icons were kept. It was also used as determinative when writing the names of different deities. That is why it once had the wAs scepter and Ma'at's feather at other time; Gardiner, A. H. Egyptian Grammar: being in Introduction to the Study of Hieroglyphs, Griffith institute, Ashmolean Museum, Oxford, 1957, 502 (sign R.12).

(26) Hannig, R., Großes Handwörterbuch:Ägyptisch-Deutsch (HL1), Marburger Edition, 2005, $1217\{43107\}$.

${ }^{(27)}$ Helck, V., Das Bier im Alten Ägypten, Berlin, 1971, 105.

(28) Wb. I, 26.1.7; Owing to the precedence of the feminine name of the deity, the Researcher has preferred to use the word "goddess" instead of "god" in the title of this paper. 
of the deity. ${ }^{(29)}$ The name was also mentioned in the deity name list without a determinative in the form 4 .(30)

These two forms were linked together in and to express the goddess IAt through the incantation no. 211 that is found in pyramid texts. It appeared in the pyramid texts of King Unas and it appeared as in the pyramid texts of King Teti in the same phrase that states: ${ }^{(31)}$

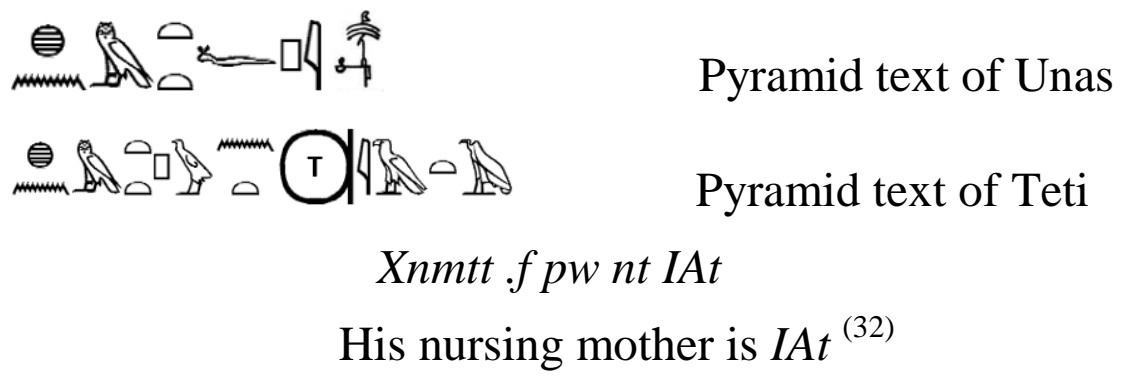

Faulkner referred to it in his translation as the dairies deity.

(29) Hannig, Großes Handwörterbuch:(HL1), 3000, \{43090\}; the word has appeared in Berlin Dictionary in the form 12 without a divine determinative to mean residence, place or mountain; Wb. I, 26, 9-13; FCD, 7; Also, $\mathbb{1} \circ$ औी has appeared in the incantation no. 1019 in the coffin texts with the determinative of a sitting god. Faulkner; however, translated it as mount in CT VII, 1019, 241a [Anubis over his] mount; CT III, spell 1019, 121; Barguet, P., CT, 604, 1019 (Pap. Gar. II). The question then is whether this word means the residence of the deity (and in this case who the deity is?) or does it refer to the masculine form of IAt?

${ }^{(30)}$ Hannig, Großes Handwörterbuch, 1216 \{43090\}.

(31) Sethe, Pyr 1, Spruch 211, 131d; Wilkinson, T., A., Royal Annals of Ancient Egypt: The Palermo Stone and its Associated Fragments Routledge, London, 2000, 100; Helck, Das Bier, 105.

${ }^{(32)}$ Mercer, The Pyramid texts, vol. 1,Library of Alexandria, 1952, Utterance 211, 131d, 58; Faulkner has translated the same statement using the first singular pronoun "My mother who has fostered (embraced) me is IAt"; Faulkner, Pyr, Utterance 211§131, 40.

${ }^{(33)}$ Faulkner, Pyr, Utterance $211 \S 131,40$, footnote 2. 


\subsection{IAt as a Dairy Deity}

One of the most ancient evidence that linked the deity IAt to

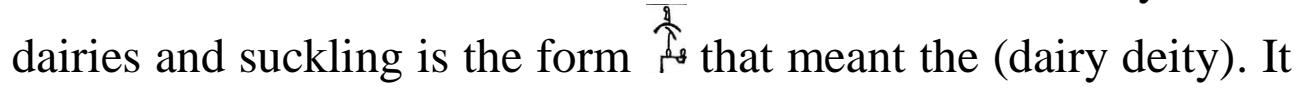
was part of the incantation no. 578 that is concerned with resurrection among King Pepi's pyramid texts in a phrase stating:

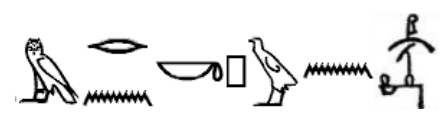

$m r n . k p w n$ IA.t ${ }^{(34)}$

"In thy name, the dairies deity"(35)

Faulkner highlights the link between the two written forms that appeared in the same manners and symbolizing the Milk-goddess. ${ }^{(36)}$ Leitz, agrees to the same point concerning the written form and its function as deity associated with milk in ancient Egyptian creed. ${ }^{(37)}$ In addition to its being mentioned in the pyramid texts as a milk-goddess and responsible for taking care of and breast feeding the king as it is previously mentioned. ${ }^{(38)}$

The name had also appeared on the pillars nearby the tomb of 粪 $H t p-H r-n-P t H$ in Giza that dates to the Old Kingdom. It appeared in the form ${ }^{\beta}(39)$ representing the $w A s$ scepter crowned by the crescent and then the justice feather that stands for the goddess Ma'at. The connection between IAt as a name for the deity and the clear articulation of its comprising letters IAt as well as its function role as a milk goddess links it

${ }^{(34)}$ Sethe, Pyr 2, Spruch 578, $1537 \mathrm{~b}$.

${ }^{(35)}$ Faulkner, Pyr, Utterance 578§1537, 234.

${ }^{(36)}$ FCD, 7.

${ }^{(37)}$ Leitz, C., Lexikon der ägyptischen Götter und Götterbezeichnungen: Band I: A-y, OLA, Peeters Publishers, France, 2002, 96.

${ }^{(38)}$ Wilkinson, T. A., Early Dynastic Egypt, Routledge, London, 1999, 248.

${ }^{(39)}$ Urk.IV, 231.7. 
to the written form $\stackrel{\frac{2}{3}}{\frac{1}{p}}$. This emerged through the word iAtt which is written in a way like $\lceil$ and $\$$. It used to represent the scepter $w A s .{ }^{(40)}$ It was written as ${ }^{4}$ iAtt. It meant milk and cream. ${ }^{\left({ }^{4}\right)}$ It

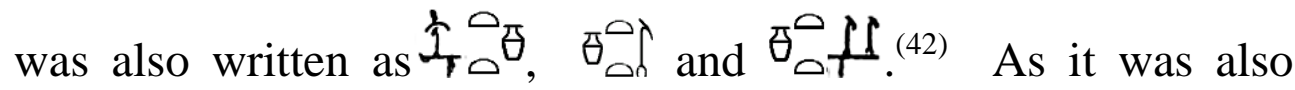

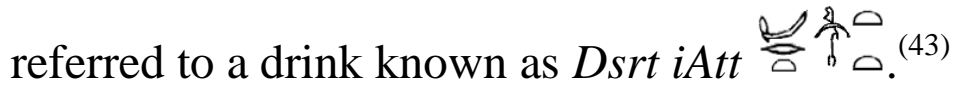

Faulkner referred to it as $1^{2}$ Dsrt iAtt which meant a: milky drink. ${ }^{(44)}$ It was also mentioned in the Pyramid texts of King Unas in incantation no. 149 on the northern part of the burial chamber. It was part of the sacrifice rituals used to prepare the offerings table as a sort of drinks. ${ }^{(4)}$ It was written in the forms Dsrt of (46) and sDrt iAttt 年 st $^{(47)}$ meaning: cream $^{(48)}$ in the phrase:

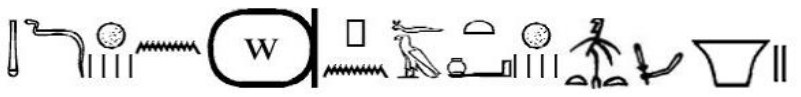

Dd mdw sp 4 n Wnis pn fAt sp 4 Dsrt iAtt iab $2^{(49)}$

"Reciting four times to Unas and to increase the offerings four times two pots of creamy drink".

Faulkner translates this last part as: "two pots of sacred milk". ${ }^{(50)}$ Helck, meanwhile, translates it as: the drink of milk. ${ }^{(51)}$

${ }^{(40)}$ Ivanova, Milk, 2.

(41) FCD, 7; Gardiner, Egyptian grammar, 509 (S.40); 503 (R19); Meeks, D., Année lexicographique. Égypte ancienne, Tome I, Paris, 1980, 11 (77.0116), 1980.

${ }^{(42)}$ Wb. I, 27, 1-4.

(43) Wb. I, 27, 3.4.

(44) FCD, 325 .

(45) Allen, J. P. and Peter Der Manuelian, Writings from the Ancient World: The Ancient Egyptian Pyramid Texts, Society of Biblical Literature, No. 23, Atlanta, 2005, recitation 108, 19, 26; Helck, Das Bier, 19.

${ }^{(46)}$ Helck, Das Bier, 19.

${ }^{(47)}$ Sethe, Pyr 1, Spruch 146, 89 b.

(48) Allen, Pyramid text, recitation 108, 26.

${ }^{(49)}$ Sethe, Pyr 1, Spruch 146, 89 b. 
According to Mercer, it is translated to mean a beer peculiar to Thebes ${ }^{(52)}$ as he considered the word used wAst not iAtt.

Meeks suggests that Dsrt iAtt means a lotion made of milk. It was stated in medical scripts that it was used to treat asthma. It was a sort of beverage made up of a mashed and refined plant to which milk is added. The goddess Hathor had been linked to this beverage and she was known as the mistress of Dsrt beverage. ${ }^{(54)}$ Henceforth, this goddess has been linked to milk, nourishment and breastfeeding through its particular name IAt. ${ }^{(55)}$ Sethe has also assured this role during the epoch of the New Kingdom. ${ }^{(56)}$

During the Hellenic era, the expression anx wAs was employed. It was used to mean life and authority and was used to refer to milk. An example is the phrase: Ssp .n .i anx wAs r snp $D t$ which means: I have received the milk for eternal renewal. This notion was confirmed through the scripts associated with offering milk to renew the monarchy. ${ }^{(57)}$ The Researcher refers to this term in order to affirm the continuity of the connection between the wAs scepter - which was one written form of the goddess IAt - with milk until the end of Ancient Egyptian history. ${ }^{(58)}$

\footnotetext{
${ }^{(50)}$ Faulkner, Pyr, Utterance $146 \S 89,29$.

${ }^{(51)}$ Helck, Das Bier, 105.

${ }^{(52)}$ Mercer, PyrTranslation, Utterance 146, 89 b, 47.

${ }^{(53)}$ Meeks II, 13 (78.0126), 1981.

${ }^{(54)}$ Qābīl, Muhammad 'Alaa, "al mašrubāt fî Miṣr al-Qadīma”, Mağālt al 'lum al- 'Arbīya wa al-insānīya, Qassim University, Vol.2/2, 2009, 315-328.

${ }^{(55)}$ Ivanova, Milk, 3; Wilkinson, Royal Annals, 100.
}

(56) Sethe, K., Urkunden des AegyptischenAltertums in Verbindungmitanderen Herausgegeben: Urkunden der 18. Dynastie, I, J. C. Hinrichs'sche, Leipzig, 1914, 107; Urk. IV, 231, 15 .

${ }^{(57)}$ Ivanova, Milk, 6.

${ }^{(58)}$ In addition to the connection between the wAs scepter and IAt, it is also associated with other gods such as IgAy and Isis. The wAs scepter is a bar that ends in an animal head and at the bottom has animal feet. It stands for authority and usually monarchs and deities are portrayed holding it in different scenes; Martin, K., "Was-Zepter", LÄ VI, 1152-3; the wAs scepter was used to write the name of the god Osiris. Brougsch was one of the pioneers 
The name is generally written in the form of the wAs scepter? and the vulture $M w t$. Thus, some argue that it should be articulated as Amwt, not IAt. ${ }^{(59)}$ The Researcher; however, does not agree to this view-point since IAt was sometimes written

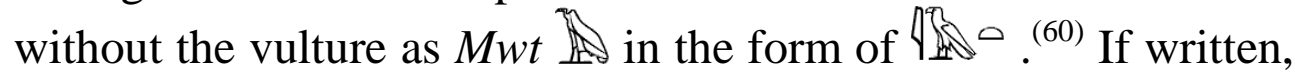
it was to be added at the end of the word after the uni-phonemes. This means it had its own determinative. A determinative, as it is well- known, is an additional symbol added at the end of the world. It is not articulated and has no phonemic value. It plays two important roles. The first is to determine that the symbols preceding it are phonemic and not pictorial. The other is contributing to defining the meaning of the word. ${ }^{(61)}$ It helps in determining how the word is presented especially that there are no separators between letters and words.

who indicated similarities in the way both Thebes and Osiris are written in terms of using the wAs scepter 1 . The name Osiris appears in several forms where the scepter is used such

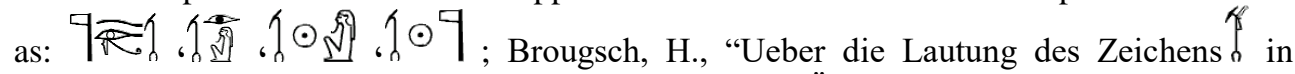
demNamen des Osiris und des thebanischen Nomos", ZÄS 2, 1967, 67-8; Derchain-Urtel, M. Th., "Die Namen der Gotter", OLA 84,in Clarysse, W., Schoors, A. and Willems, H., (eds), Egyptian Religion, the Last Thousand Years (Studies Dedicated to the Memory of Jan Quaegebeur), Part I, Leuven, 1998, 578-9.

${ }^{(59)}$ Helck, W., "Iat (iAt)", LÄ III, 114; Wilkinson, Early Dynastic Egypt, 248.

${ }^{(60)}$ Hannig, Großes Handwörterbuch, 1216 \{43090\}.

${ }^{(61)}$ Allen, Middle Egyptian, 3; Collier, M., Middle Egyptian Course: introduction to the ancient Egyptian language and Script, 2004, 6; Hoch, J. E., Middle Egyptian Grammar, vol. 15, Mississauga, Ont., Benben Publications, 1997, 18; Loprieno, A., Ancient Egyptian: a linguistic introduction, Cambridge University Press, 2004, 13; Gardiner, Egyptian Grammar, 31 §24; Griffith, F. L., a Collection of Hieroglyphs a contribution to the History of Egyptian writing, Archaeological survey of Egypt, sixth memoir, offices of the Egypt Exploration Fund, London, 1898, 5; Erman, A., Egyptian Grammar with Table of Signs, Bibliography, Exercise for reading And Glossary, Translated by, James Henry Breasted, London, 1894, 16.

${ }^{(62)}$ Hoch, Middle Egyptian Grammar, 18. 


\section{2- The Religious Significance of the Goddess Based on the Script Evidence}

The archeological evidences that should help us to trace the earliest emergence of the goddess IAt (or its masculine form) are not sufficient so far. The most important resource dates to the First Dynasty as Wilkinson indicates the emergence of the goddess IAt on the Palermo Stone in the fifth year of an anonymous monarch from the same Dynasty. This is perhaps a reference to what had been devoted to the icon of the goddess IAt. $^{(63)}$

The significance of Palermo Stone is attributed to the fact that it records the royal yearbooks for monarchs from the Old Kingdom as well as their reigns and achievements. It starts with monarchs dating back to predynastic Egypt and continues to encompass monarchs who reigned until the mid - Fifth Dynasty. The recto is recorded in the royal yearbooks dating back to the Fourth Dynasty while the verso is recorded in the royal yearbooks dating back to the end of the Fourth through the midFifth Dynasties. ${ }^{(64)}$

The second line includes a phrase referring to the fifth year of King Djer's rule stating: Smsw-Hr mst IAt $m$ H 5 Ssp 1. It means:

${ }^{(63)}$ Wilkinson, Toby, Early Dynastic, 248; Palermo Stone is a huge mass of black basalt comprising six parts which is perhaps attributed to Heliopolis. The largest piece of it is currently found in Palermo Museum, Italy. It has been there since October 1877 under the no. 1028. It is $43.5 \mathrm{~cm}, 25 \mathrm{~cm}$ wide and 6.5 thick. The other pieces are found in the Egyptian Museum which is home to four pieces while the last piece is found at Petrie Museum in London. The Stone dates back to the Fifth Dynasty; H. Shih-Wei, the Palermo Stone: The Earliest Royal Inscription from Ancient Egypt, Altoriental Forsch., AkademieVerlag, 37, 2010, 68, 69; Scalf, F., "Rereading the $7^{\text {th }}$ Count of Snefru in the Palermo Stone", GM 220, 2009, 89. The stone records the yearly events, festivals and rituals. It is divided into records each beginning with the sign Renpet which indicates the year. Schäfer has examined the stone records starting from the second record; Schäfer, H,.

Ein Bruchstück altägyptischerAnnalen, Verlag der königlichen Akademie der Wissenschaften Berlin, 1902, 2, pl. 1.

${ }^{(64)}$ H. Shih-Wei, "the Palermo Stone",78. 
Horus followers performs an (image) to $I A t$, with five arms and one fist. ${ }^{(65)}$ Schafer; however, read it as $s S A t$ and interpreted it as referring to the birth of $s S A t$ and not IAt $m s(w) t s S A t$, which means: the journey of the followers of Horus and the birth of $s S A t .^{(66)}$ Another scholar read it asYAm.t and occurring in the sixth year of King Djer's reign, and not the fifth as indicated by Wilkinson (Fig. 1). It was written as follows: Smsw Hr mst YAm.t mH 5 Ssp 1. It means: the followers of Horus and the birth of the goddess YAm.t (and the Nile Measurement) with five arms and one finger. ${ }^{(67)}$ Both Wilkinson and Schafer agree that $m s t$ (birth) is used here to symbolize making a devoted statue of the deity. ${ }^{(68)}$

The Researcher agrees with Wilkinson concerning the idea that what is written in the script refers to IAt. It seems similar to that found in incantation no. 578 . which is referred to previously. ${ }^{(69)}$ That is the same form in which it appeared on the pillars of HTtp-Hr-n-PtH tomb ${ }^{\beta}$ which is referred to previously as well. ${ }^{(70)}$ The Researcher deduces from Palermo Stone the absence of the complete star form which is the symbol of the goddess $s S A t$ 米. ${ }^{(71)}$ It is the form that appears and it does not stand for the goddess $S S A T$; but it is closer to the way in which the name of IAt is written based on the previously tackled forms (fig. 2).

${ }^{(65)}$ Wilkinson, Toby, Royal Annals, 100.

(66) Schäfer, EinBruchstückaltägyptischerAnnalen, 3;

http://xoomer.virgilio.it/francescoraf/hesyra/palermo.jpg.

(67) Shih-Wei, "the Palermo Stone", 82; through the linguistic investigation tackled in the paper for the name of the goddess.

${ }^{(68)}$ Wilkinson, Toby, Royal Annals, 100; Schäfer, EinBruchstückaltägyptischerAnnalen, 2.

${ }^{(69)}$ Wilkinson, Royal Annals, 100.

${ }^{(70)}$ Urk.IV, 231, 7.

${ }^{(71)}$ FCD, 246; Gardiner, Egyptian Grammar, 503. R.20 


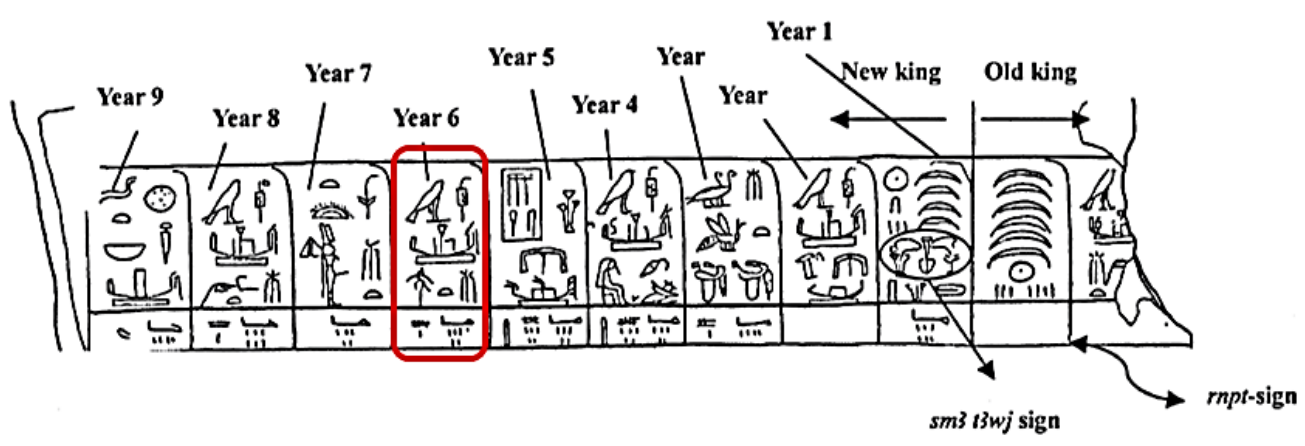

Fig. 1: Stating the name of IAt on the second record of Palermo Stone the sixth year of King Djer reign.

H. Shih-Wei, The Palermo Stone, 79, fig.13.
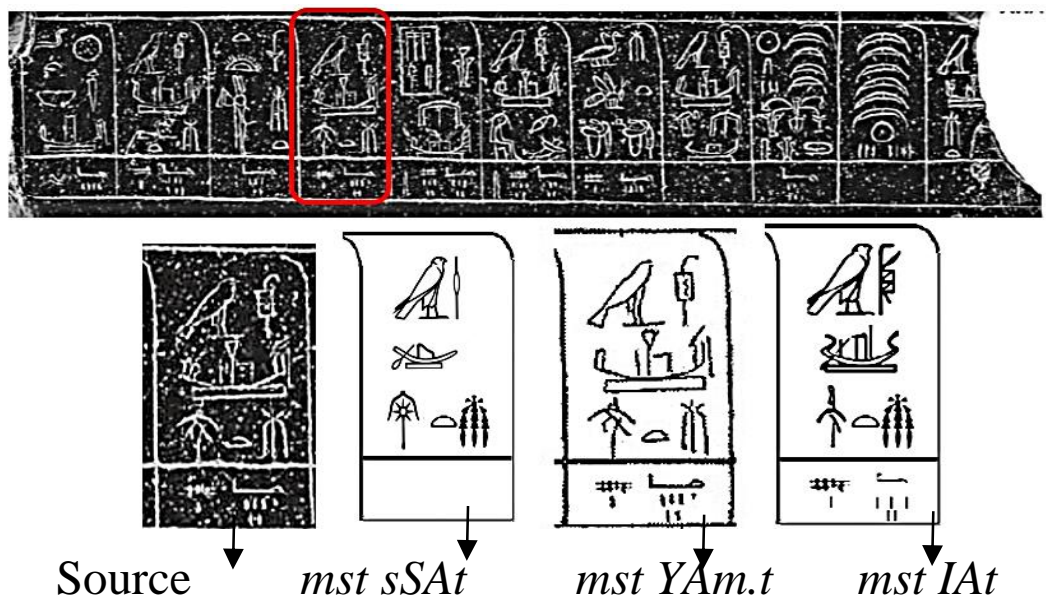

(Palermo Schafer's Shih-Wei's researcher's

Stone) translation translation translation

Fig. 2: A detail clarifying how the name of the deity IAt is written on the second record of Palermo Stone - after the Researcher.

Other textual evidence dating back to the same era is what has been stated among the Pyramid texts in the incantation no. 578 found on the eastern and western walls at the hall of King Pepi's Pyramid. It is part of the incantations related to entering 
and getting out of the tomb so that the deceased becomes Osiris by dusk, in the following phrase: ${ }^{(72)}$

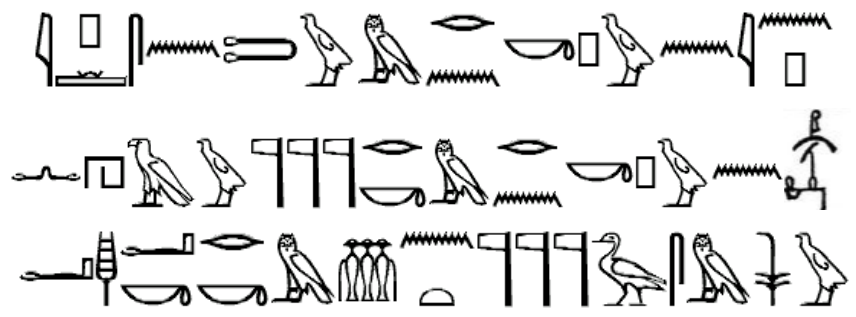

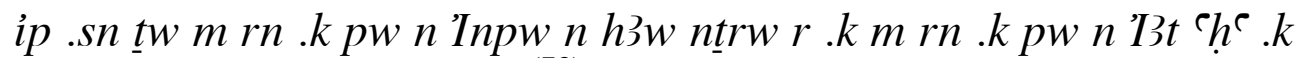
$r . k m$ hnt $n t$ ntrw $s 3$ smsw ${ }^{(73)}$

"They are getting to know thee in thy name (Anubis). Gods will not stand against thee in the name of the milk deity. Stand ahead of all the deities, thee the eldest son". ${ }^{(74)}$

The name of the goddess was also mentioned at the burial chamber of King Unas. It was stated on the eastern part among the sacrifice rituals in incantation no. 211 which is referred to previously: ${ }^{(75)}$ "Hunger is the sin of Unas; he doth not eat it. Thirst is Unas sin; he doth not drink it. Unas shall give bread to his foster parent; the milk goddess. She is one who shall make him live. She is the one who really gave birth to him, when Unas was merely a semen drop in the night, Unas was born at night". (76)

\section{3- The Masculine Form of IAt in the Available Scenes}

According to Wilkinson, IAt is the milk goddess and is responsible for taking care of babies. She is mentioned in these ways in the Pyramid Texts where the king states: "my fostermother is Iat", and she is who nourishes me as aforementioned in

(72) Allen, Pyramid text, recitation 520, 173.

(73) Sethe, Pyr 1, Spruch 578, 1537a-b; 1538a.

(74) Allen, Pyramid text, recitation 520, 184.

${ }^{(75)}$ Sethe, Pyr 1, Spruch 211, 131a-d.

(76) Allen, Pyramid text, recitation 144, 29, 30. 
(PT131). ${ }^{(77)}$ It is noteworthy while examining this goddess to refer to its form in Ancient Egyptian art. The milk goddess has appeared in its feminine form IA.t since the Old Kingdom. Since the New Kingdom, particularly the Eighteenth Dynasty, it appeared in the masculine form IAty determinative as a milk goddess. ${ }^{(78)}$ It was linked to birth, renewal and breastfeeding. ${ }^{(79)}$ This might explain the emergence of this goddess in the form of a man among the scenes of divine labour of Hatshepsut's Temple. ${ }^{(80)}$ It can be described through the scene as the milk deity owing to its masculine form and the milk pot found on top of his head. ${ }^{(81)}$ Thus, based on this form it is the deity providing the baby with milk.

\subsection{The Role of IAt (in its masculine form) in Divine Labour}

The deity IAt appeared on the northern wall on the second surface among the divine labour scenes no. 12 and 13 of Hatshepsut at Deir el Bahari Temple. It is portrayed with a milk pot on its head to express its essence. ${ }^{(82)}$. The queen mother is portrayed sitting on a high chair below a row of (tyt) symbols. Before her, two forms of Hathor are portrayed with a cow head breastfeeding the baby-girl and her Ka. This scene is followed by two other scenes of Hathor in the form of a cow to provide the baby-girl with milk. It is well-known that the current scenes are not original. They were added to replace the original scenes. However, reminiscent of the horns of the cow Hathor are found on the walls. Also the accompanying engraving is found

${ }^{(77)}$ Wilkinson, Complete Gods and Goddesses, 145, 146.

${ }^{(78)}$ Wb. I, 26.17; Ivanova, Milk, 3.

${ }^{(79)}$ Helck, "Iat (iAt)", LÄ II, 114.

${ }^{(80)}$ Naville, Deir el Bahari, fig.53.

${ }^{(81)}$ Helck, Das Bier, 105.

${ }^{\left({ }^{82}\right)}$ Helck, Das Bier, 105; PM II, 349, (20-1). 
(although in a bad condition): mna Hmt.s Hna kAw .s nbw, "Breastfeeding her Majesty and her Ka". ${ }^{83)}$

This scene is full of nurses. Twelve nurses are portrayed carrying babies with the symbols of $\mathrm{Ka}$ and the goddess Neith above their heads. The Ka of the babies comprise Twelve figures as well two images of Hathor in the form of the cow. The last scene on the western wall depicts the nurses handing the divine baby to two masculine forms of gods. ${ }^{(84)}$ These are the gods Hapi in the double aspect femininity and masculinity and IAt the milkgod, ${ }^{(85)}$ the milk- bringer who is depicted with a milk pot on his head. Both, in turn, hand both babies to three goddesses sitting in Osiris attire. Then god Thoth hands the two babies to Amun (figs. 3 and 4). ${ }^{(86)}$

Some argue that the form of the god here represents the masculine form of the milk god known as IAty that appeared in the scene as a man in addition to its feminine form. ${ }^{(87)}$ In the light of the previously data as well as investigating the linguistic aspect of the name, it can be said that the IAt, the milk goddess in its feminine form takes the determinative of the $M w t$ vulture. It is associated with the process of fostering and breastfeeding the baby. Meanwhile, the masculine form of the milk bringer deity is IAty. $\mathrm{He}$ is responsible for only providing the baby with milk. This is in accord with several examples of goddesses in Ancient

\footnotetext{
${ }^{(83)}$ The Researcher shall write the accompanying text in another spot.

${ }^{(84)}$ Naville, Deir el Bahari, 17, 18, fig.53.

(85) Brunner, H., "Die Geburt des Gottkönigs: Studien zur Überlieferung eines altägyptischen Mythos', ÄA 10, 1964, 138, szene XIII, Taf. 13; PM II, 349, (20-1).

(86) Urk. IV, 231, 15; 201; unfortunately, the accompanying text for this scene is broken and does not reveal the name of these goddesses. When comparing the scenes of divine labour of Amenhotep III at Luxor Temple in the first record located on the western wall of the labour chamber, the handing of the baby is done by the god Hapi and then the god HkAw; Naville, Deir el Bahari, Part II, 18; Gayet, Louxor, 105, 106, pl. LXVII, fig. 187; LD. III, pl.75a.

${ }^{(87)}$ Ivanova, Milk, 5.
} 
Egyptian faith such as the deity Taweret in its feminine form and as hippopotamus in its masculine form.

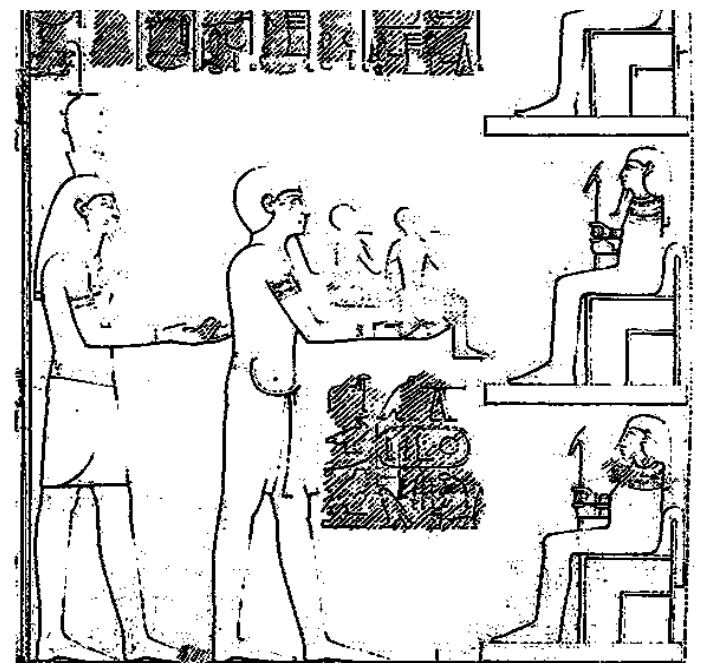

Fig. 3: The God IAt (in its masculine form) in Divine Labour,

Hatshepsut temple, Deir el Bahari. Naville, Deir el Bahari, Part II, fig.53.

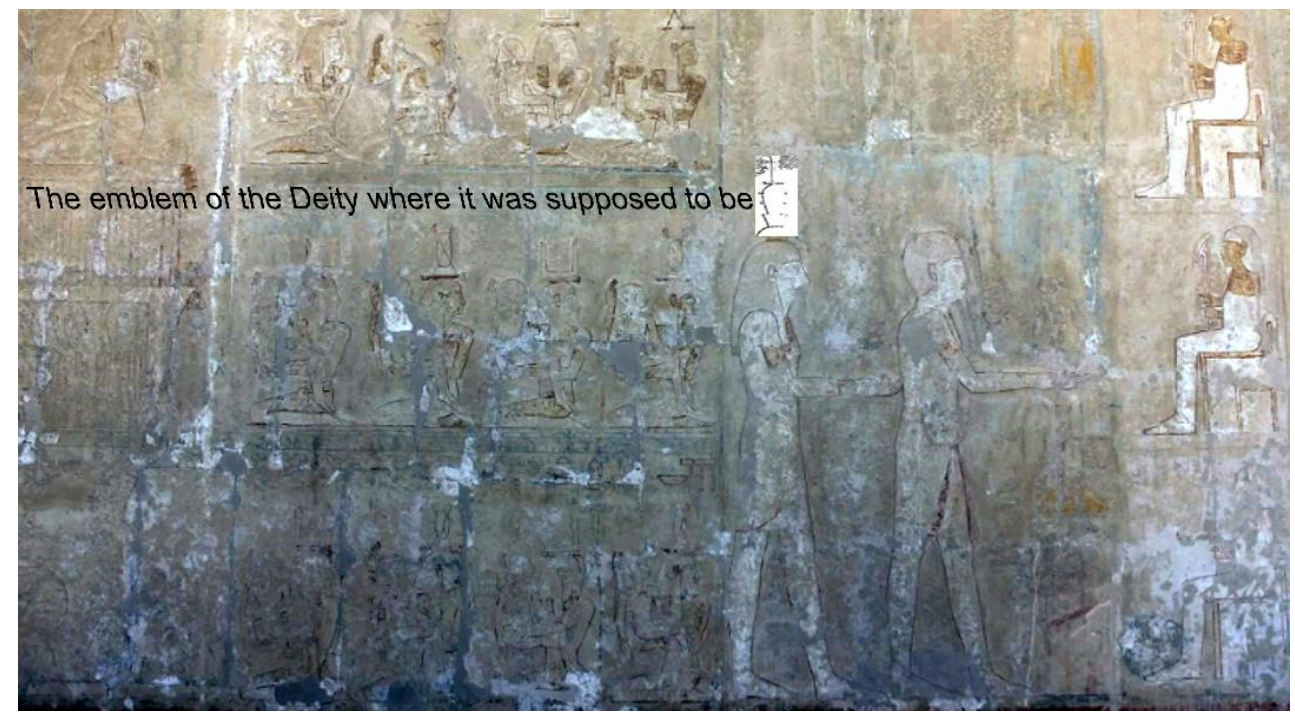

Fig. 4: The God IAt (in its masculine form) in Divine Labour, Hatshepsut temple, 
Deir el Bahari. The photo was taken by the Researcher in 14/4/2016. ${ }^{(88)}$

Similarly, is the god Hapi who appears in dual nature to express both femininity and masculinity simultaneously. Its breasts and dangling abdomen are symbol of fertility. Meanwhile, its posture, firm moral and renewal through the Nile and its flood symbolize its masculinity. ${ }^{(89)}$ This is perhaps why IAty has appeared her behind the god Hapi, i.e. due to their similar masculine forms. Accordingly, IAty has not appeared in its masculine form before the New Kingdom.

It is noteworthy that IAty as portrayed in the divine labour scene of Queen Hatshepsut is not generally associated with breastfeeding because of its masculine form. It provided the baby with milk through the symbol it carried on top of his head. This is affirmed through the accompanying texts of the divine labour scenes where Amun asks the breastfeeding goddesses (Nekhbet, Serket, Wadjet, Hathor and Hesat the cow) to breastfeed the newly-born monarch: ${ }^{(90)}$

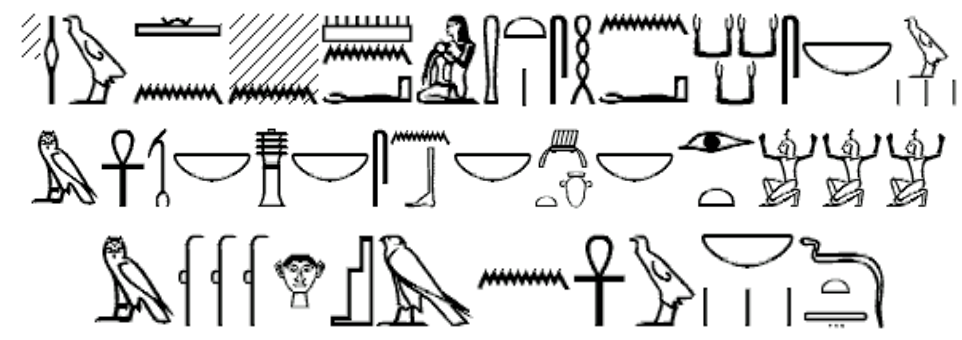

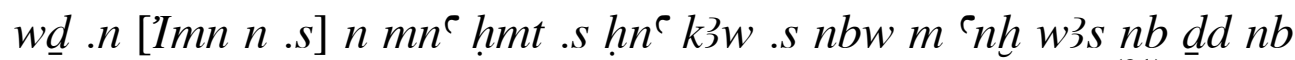
snb $n b 3 w t-i b$ nb irt ḥhw $m$ rnpwt ḥr st ḥr $n^{\complement} n h w w b w d t^{(91)}$

(88) The Researcher noted during his recent visit to the Temple of Hatshepsut on the West Bank in 14/4/2016 that the state of the scene has become bad and the emblem of god IAt is vanished.

${ }^{(89)}$ Wilkinson, Complete Gods and Goddesses, 106, 10; see also: Derchain-Urtel, "Die Namen der Gotter", 583-6.

${ }^{(90)}$ Ivanova, Milk, 6.

${ }^{(91)}$ Urk.IV, 230, 15-17. 
"Amun hath ordered them to breastfeed her majesty along with all her Kas. She is to be granted life, all power, all stability, all health and happiness in order to work millions of years on the throne of Horus in favour of all the living eternally".

This is considered one of the significant texts as it highlights the deities responsible for breastfeeding in this process. Amun has also asked them to breastfeed to affirm that it is not IAt who is responsible for this role.

\subsection{The Emblem of $I A t$}

The deity IAt is portrayed with a milk pot above his head as is seen through the previous analysis of the scene as . This emblem directly symbolizes the functional role of the deity in Ancient Egyptian theology. It confirms its association with milk since this emblem is a pot of milk used to add milk. Gardner remarks that it was covered with a plant leaf ${ }^{(93)}$

\section{4- Priests of IAt}

In addition to what is previously mentioned, the religious significance of IAt deity emerged through the texts indicating the existence of its peculiar priests. These texts were found during the restoration and cleansing the entrance of the tomb Tsn It is sometimes written as superintendent of the scribers and the head of ten of Upper Egypt. ${ }^{(94)}$ Three engraved limestone masses were found

(92) Ivanova, Milk, 6.

(93) Gardiner, Egyptian Grammar, 530 (sign W20); Hannig, Großes Handwörterbuch, 106 $\{3538\}$.

(94) The tomb of Tsn dates back to the Old Kingdom. The tomb is found to the north of the tomb of Bw-nfr that is sculptured in the rocks at Giza Plateau to the west of Fefi's tomb (the Priest of King Khefren). Tsn had held several titles; Hassan, S., Excavation at Gîza: with special Chapters on Methods of Excavation, the false-door, and other Archaeological and religious subjects, vol. V, Government Press, Bulâq, Cairo, 1944, 261-79. 
representing parts between two doors sills belonging to two different people. One of these parts is a sill to an entrance for a person called Nes 7 . His rocky mass comprised two rows of engravings. On the second row, the following was written: ${ }^{(95)}$

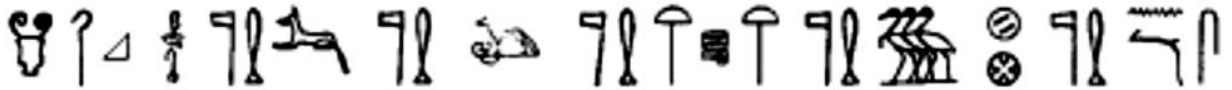

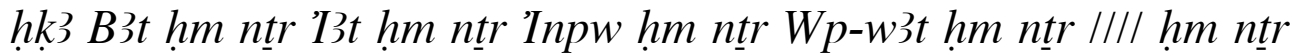
b’w nhn hm ntr Nis

"The ruler of goddess Bat, the priest of goddess $I A t{ }^{(96)}$, the priest of god Anubis, the priest of god Webwat, the priest of ..., the priest of Nekhen Spirits and the priest of Nes".

The significance of this text refers to Nes as a priest for several deities including IAt. This, in turn, refers to the importance of this deity among the major deities in Ancient Egyptian religion thought. It also affirms the existence of priests peculiar to this deity in order to perform various religious rituals.

The Metropolitan Museum has two highly significant pieces; they are one of the most well-preserved pieces dating back to this early period. The importance here that they refer to the priests of the deity. The first scene portrays a corner of limestone from the chamber of a palace official Akhet-Hotep with his names and titles. ${ }^{(98)}$ He depicted receiving offering holding a long staff and a short scepter. He is portrayed on the corners of this part of the chamber twice in different attire. Engravings above these two corners were found showing the titles of Akhet-Hotep are

${ }^{(95)}$ Hassan, Gîza, vol. V,276.

${ }^{(96)}$ Hassan, S. refers to IAt here as the milk goddess; Gîza, vol. V, 276, footnote 1.

${ }^{(97)}$ Hassan, Gîza, vol. V, 276.

(98) Akhet-Hotep is the official at the royal palace during King Senfru's reign. His tomb is found at Saqqara. The rocky mass is $96 \mathrm{~cm}$ and is displayed under no. 58.123; http://www.metmuseum.org/collection/the-collection-online/search/543912 
found. ${ }^{(99)}$ The right engravings read: "the superintendent of the royal Harem, the priest of IAt (the milk goddess) Akhet-Hotep". While the left engravings read: "the superintendent of the royal Harem, the priest BAstt, Akhet-Hotep". ${ }^{(100)}$ They highlight the most important posts that Akhet-Hotep has occupied (fig. 5).

The first engraving emphasizes the existence of a priest peculiar to IAt, the milk goddess. Thus, reflecting the high status in which this goddess was held. The reference to BAstt here is perhaps because it is one of the goddesses linked to breast feeding the monarch and providing milk. This is clear on the incantation no. 508 of the Pyramids texts where one phrase states: $m H d y n$ sw $m w t$.f BAstt, "He was breastfed by his mother BAstt". (101)

(99) Fazzini, R. A., Romano, J. E., and Cody, M. E., Art of Eternity: master works from ancient Egypt, Brooklyn Museum of Art, 45, fig. 8.

${ }^{(100)}$ Scott, N., "Two Reliefs of the Early Old Kingdom", MMA 19, 1961, 194-5; Cherpion, N., "The Human image in Old Kingdom non-royal reliefs", in: Arnold, d. Grzymski, K. and Ziegler, C., (eds), Egyptian Art in the Age of the Pyramids, MMA, New York, 1999, 106, fig. 64.

${ }^{(101)}$ Ivanova, Milk, 15; for more information about this incantation, check: Sethe, Pyr2, Spruch 508, 1111a-c; Faulkner, Pyr, Utterance 508 §1111, 183; Mercer, PyrTranslation, Utterance 508, 1111a-c, 190. 


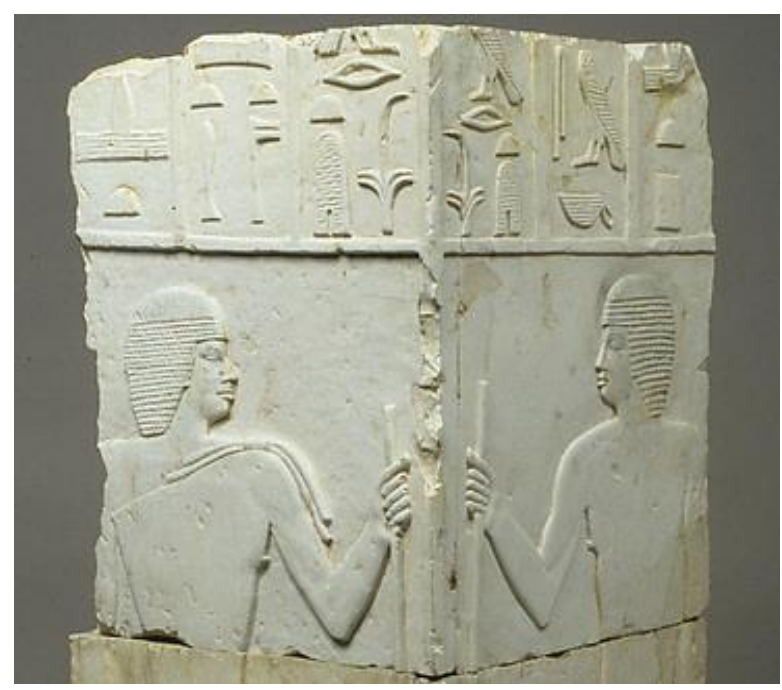

Fig. 5: The limestone corner from Akhet-Hotep's tomb.

http://www.metmuseum.org/collection/the-collectiononline/search/543912 ${ }^{(102)}$

\section{Conclusions}

Literature about some Ancient Egyptian deities and their functional roles still require further studying and analysis; particularly those associated with social aspects. IAt was one of these deities. The Researcher attempts to discuss an obscure god/goddess $I A t$ which is only known from a limited corpus and documented up through the New Kingdom. Through this paper, the Researcher concluded that IAt was existing in a dual form (feminine and masculine). God/goddess IAt was mentioned since the earliest dynasties were established. Meanwhile, the masculine form was associated to providing the royal baby with milk. It used to be portrayed with a milk pot on top of his head. Thus, the remarkable motto of this deity was the milk pot. It is noted that

${ }^{(102)}$ http://www.metmuseum.org/collection/the-collection-online/search/543912, retrieved 25/1/2016, 3:00 pm; unfortunately, the part that includes the name of the goddess IAt is vanished, where the upper part of the piece has lost. 
the Ancient Egyptian artist portrayed this deity during the divine labour process according to the role it played, as was the case in Hatshepsut temple.

As for its linguistic nature, the name of the deity is derived from iAtt which means milk. The written form of the word was always linked to the $w A s$ scepter and the vulture $M w t$, hence confirming the dual nature of the deity. It is read as IA.t in case of the goddess and iAty in case of the god. It was written sometimes without a determinative.

The religious significance of the deity is highlighted through the numerous times it was mentioned within historical texts. Examples are found on Palermo Stone, the Pyramids texts as well as various tombs. Moreover, it used to have its own priests; which means that rituals peculiar to this deity were performed. The masculine form emerged since the New Kingdom. It is noteworthy that the question of whether the deity in its - feminine and masculine forms - continued to exist until the end of the Ancient Egyptian history or not remains unanswered. The Researcher has found any texts or scenes that provide an answer to this. 


\section{Abbreviations}

AJMG American Journal of Medical Genetics, Wiley-Liss, United States.

De Buck, A., The Egyptian Coffin Texts, 7 vol., Chicago. Illinois.

CT

FCD Faulkner, R. O., A Concise Dictionary of Middle Egyptian, Oxford.

Faulkner, R. O., The Ancient Egyptian Coffin Texts, 3 vol., London.

FCT

LÄ Lexikon der Ägyptologie, Wiesbaden.

LD

Lepsius, C.R., Denkmäler aus Aegypten und Aethiopien, Berlin.

Faulkner, Pyr Faulkner, R. O., The Ancient Egyptian Pyramid Texts, Oxford.

MIFAO Mémoires Publiés par Les Members de L'Institut Français d'archéologie Orientale, (Le Caire).

MMA

The Metropolitan Museum of Art, Dept. of Egyptian Art, New York.

Orientalia Lovaniensia Analecta, Leuven.

OLA

Porter, R. \& Moss, R., Topographical Bibliography of Ancient Egyptian Hieroglyphic Texts, Reliefs and Paintings, 8 vol., Oxford.

PM

Pyr

Sethe, K., Die Altägyptischen Pyramidentexte, Leipzig, Glückstadt.

Urk IV

Sethe, K., Urkunden der 18. Dynastie, Leipzig.

$W b$.

Erman, A. \& Grapow, H., Wörterbuch der Aegyptischen Sprache, 7 vol., Berlin.

ZÄS

Zeitschrift für ägyptische Sprache und Altertumskunde, Leipzig, Berlin. 


\section{Bibliography}

- Allen, J. P., and Peter Der Manuelian, eds., Writings from the Ancient World: The Ancient Egyptian Pyramid Texts, Society of Biblical Literature, No. 23, Atlanta, 2005.

- Allen, J., Middle Egyptian an Introduction to the Language and Culture of Hieroglyphs, Second Edition, Cambridge, 2010.

- Andrews, C., Amulets of Ancient Egypt, Published for the Trustees of the British Museum, British Museum press, 1994.

- Brougsch, H., "Ueber die Lautung des Zeichens des thebanischen Nomos", in: ZÄS 2, Leipzig 1967, 67-72.

- $\quad$ Bunson, M., Encyclopedia of Ancient Egypt, Infobase Publishing, USA, 2002.

- Cherpion, N., "The Human image in Old Kingdom nonroyal reliefs", in: Egyptian Art in the Age of the Pyramids, (ed.) D. Arnold, K. Grzymski, and Ziegler, C., MMA, New York, 1999.

- Collier, M., Middle Egyptian Course: introduction to the ancient Egyptian language and Script, 2004.

- $\quad$ Dasen, V., Dwarfs in Ancient Egypt and Greece, Oxford, 2013.

- Davidson, H. E., "Milk and the Northern Goddess', in: The Concept of the Goddess, edited by Sandra Billington, Miranda Green, London, 1996.

- De Buck, A., the Egyptian Coffin Texts, vol. II: Texts of spells 787-1185, OIP 87, the University of Chicago Press, Chicago. Illinois.

- Derchain-Urtel, M. Th., "Die Namen der Gotter", in: OLA 84, Clarysse, W., Schoors, A. and Willems, H., (eds.), Egyptian Religion, the Last Thousand Years (Studies Dedicated to the Memory of Jan Quaegebeur), Part I, Leuven, 1998.

- Dzwonek., A., Birth Houses of the Ptolemaic Period and their place in Egyptian temple building an Architectural Synthesis, 9, 10, fig.9 Article in: https://www.academia.edu/7764901/Birth_Houses_of_Ptolemaic_Period_and_t heir_place_in_Egyptian_Temple_Building._An_architectural_synthesis_-_draft, Accessed in 8/1/2016.

- Erman A., Egyptian Grammar with Table of Signs, Bibliography, Exercise for reading And Glossary, translated by James Henry Breasted, London, 1894.

- Erman, A. \& Grapow, H., Wörterbuch der Aegyptischen Sprache, Erster Bände., Akademie-Verlag, Berlin, 1971.

- Faulkner, R. O., A Concise Dictionary of Middle Egyptian, Ashmolean Museum, Oxford, 1991.

- $\quad$ Faulkner, R., the Ancient Egyptian Coffin Texts, 3 vol., England, 1973.

- $\quad$ Faulkner, R., The Ancient Egyptian Pyramid Texts, Oxford, 1969.

- Gardiner, A. H., Egyptian Grammar: being in Introduction to the Study of Hieroglyphs, Griffith institute, Ashmolean Museum, Oxford, 1957.

- $\quad$ Gayet, Al., Le Temple de Louxor, MIFAO tome Quinziéme, E. Leroux, Paris, 1894. 
- Gilligan, G., Comet Venus: part of the God king Scenario series, Troubador Publishing Ltd, Great Biritan, 2009.

- Griffith, F. L., a Collection of Hieroglyphs a contribution to the History of Egyptian writing, Archaeological survey of Egypt, sixth memoir, offices of the Egypt Exploration Fund, London, 1898.

- Gugielmi, W., "Milk", in: Oxford Encyclopedia in ancient Egypt, vol.2, editor: Redford D., Oxford, 2001.

- Guglielmi, W., "Milch (wirtschaft)”, in: LÄ IV, Tübingen, 1982, 125-127.

- Guglielmi, W., "Milchgott s. lat”, in: LÄ IV, Tübingen, 1982, 127-128.

- Brunner, H., "Die Geburt des Gottkönigs: Studien zur Überlieferung eines altägyptischen Mythos", ÄA 10, Otto Harrassowitz, Wiesbaden, 1964.

- Hannig, R., Großes Handwörterbuch: Ägyptisch-Deutsch (HL1), Marburger Edition, 2005.

- Hassan, S., Excavation at Gîza: with special Chapters on Methods of Excavation, the false-door, and other Archaeological and religious subjects, vol. V, Government Press, Bulâq, Cairo, 1944.

- Helck, V., Das Bier im Alten Ägypten, Berlin, 1971.

- Helck, W., "lat (iAt)”, in: LÄ III, Hamburg, 1980, 114.

- Hoch, J. E., Middle Egyptian Grammar, Vol. 15, Mississauga, Ont.: Benben Publications, 1997.

- Ivanova, M., Milk in ancient Egyptian religion, Uppsala, 2009.

- Kahl J, Bretschneider M, Kneissler B., Frühägyptisches Wörterbuch, Erste Lieferung A-f, Harrassowitz Verlag, Wiesbaden, 2002.

- Kákosy, L., “Heqet (Hqt)”, in: LÄ II, Budapest, Ungarn, 1977, 1123-1124.

- King, J. K., Biosemiotics in ancient Egyptian Texts: the key unlocking the universal secret of sexuality and the birth of the limitless, Envision Editions, Gaylord, Michigan, E. U. A., w.d.

- Kozma, Ch., "Dwarfs in ancient Egypt", in: American Journal of Medical Genetics, 2006.

- $\quad$ - Leitz C., Lexikon der ägyptischen Götter und Götterbezeichnungen: Band I: A-y, OLA, Peeters Publishers, France, 2002.

- Lepsius, C.R., Denkmäler aus Aegypten und Aethiopien, Bände 3, Leipzig, 1897.

- Loprieno, A., Ancient Egyptian: a linguistic introduction, Cambridge University Press, 2004.

- Martin K., “Was-Zepter”, in: LÄ VI, Gehrden, 1986, 1152-1154.

- Meeks, D., Année lexicographique. Égypte ancienne, Tome I-II, Paris, 1980-1981.

- Mercer, S., the Pyramid texts, vol. 1, Library of Alexandria, 1952.

- Naville, E., The Temple of Deir el Bahari, Part II, offices of the Egypt exploration fund, London, 1897.

- Barguet, P. Les Textes de Sarcophages Égyptiens du Moyen Empire (les édition du CERF: Latour-Maubourg, Paris), 1986.

- Qābīl, Muḥammad 'Alaa, "al mašrubāt fĩ Mișr al-Qadīma", Maǧālt al'lum al'Arbīya wa al-insānīya, Qassim University, Vol.2/2, 2009, 315-328. 
- $\quad$ Quirke, S., Exploring Religion in Ancient Egypt, Wiley Blackwell, Oxford, 2015.

- $\quad$ Robins, G., Women in ancient Egypt, Harvard University Press, London, 1993.

- Sayed Tawfic, Tārīh al-cmāra fí Mișr al-Qadīma :Luxor, Dār al-Nahḍa al-'Arbīya, 1990.

- Scalf, F., "Rereading the 7th Count of Snefru in the Palermo Stone", in: GM 220, Tubingen, 2009.

- Schäfer, H., Ein Bruchstück altägyptischer Annalen, Verlag der königlichen Akademie der Wissenschaften Berlin, 1902.

- Scott, N., Two Reliefs of the Early Old Kingdom, MMA, Vol. 19, No. 7 (Mar., 1961.

- Sethe, K., Die Altägyptischen Pyramidentexte, 2 Bände, J.C. Hinrich'sche Buchhandlung, Leipzig, 1908-1910.

- Sethe, K., Urkunden des Aegyptischen Altertums in Verbindung mit anderen Herausgegeben: Urkunden der 18. Dynastie, I, J. C. Hinrichs'sche, Leipzig, 1914.

- Sethe, K., Urkunden Der 18. Dynastie Bearbeitet und Übersetzt, Buchhandlung, Leipzig, 1914.

- Shaw I. \& Paul N., the British Museum Dictionary of ancient Egypt, the American University in Cairo Press, The Trustees of The British Museum, 1995.

- Shih-Wei, H., the Palermo Stone: the Earliest Royal Inscription from Ancient Egypt, Altoriental. Forsch., Akademie Verlag, 37, 2010.

- Touny, A. D. \& Wenig, S., Sport in Ancient Egypt, the General Egyptian Organization for Edition \& Publishing, Leipzig, 1969.

- Veiga, P., to Prevent, Treat and cure love in ancient Egypt, aspects of sexual Medicine and practice in ancient Egypt, Universidade de Lisboa, W.D.

- Wilkinson, R. H., the Complete Gods and Goddesses of Ancient Egypt, Thames \& Hudson, London, 2003.

- Wilkinson, Toby A. H., Royal Annals of Ancient Egypt: The Palermo Stone and its Associated Fragments Routledge, London, 2000.

- Wilkinson, Toby, A. H., Early Dynastic Egypt, Routledge, London, 1999.

\section{- Digital Resources:}

- http://www.catchpenny.org/thoth/Palermo/index.htm.

- http://www.catchpenny.org/thoth/Palermo/index.htm.

-http://www.metmuseum.org/collection/the-collection online/search/543912

- http://xoomer.virgilio.it/francescoraf/hesyra/palermo.jpg. 


\section{إيات (IAt) معبودة الألبان في الفكر الديني المصري القديم د.أيمن محمد أحمد \\ محمد}

ملخص:

يتتاول موضوع هذا البحث المعبودة "إيات - IAt" في الفكر الديني المصري القديم،

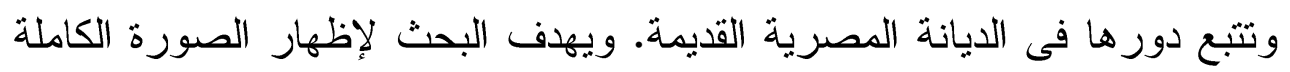
للمعبودة فى النصوص و الفن المصرى القديم، وذللك في محاولة لتأصيل نشأنها،

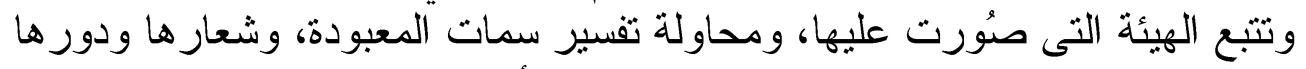

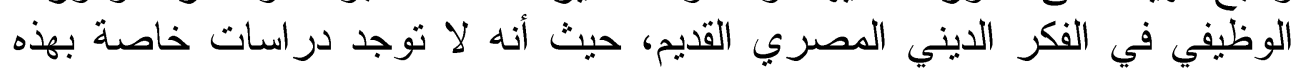
المعبودة توضح هذه النقاط.

ويحاول الباحث الإجابة عن عدة تساؤلات تتمثل فى التعرف على طريقة كتابة

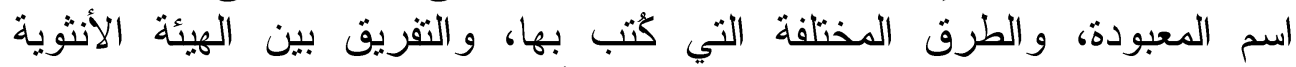

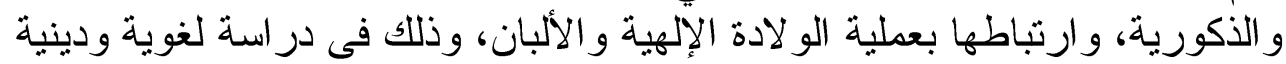

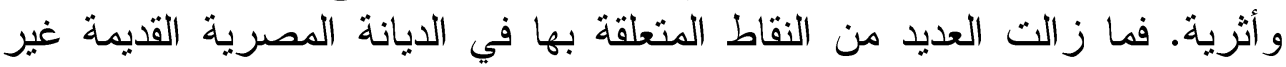

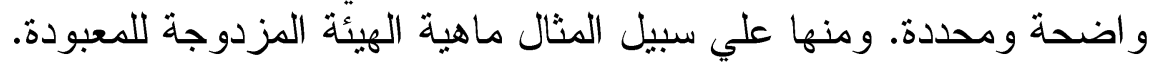

الكثمات المفتاحية:

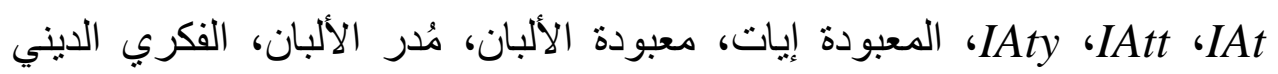
المصري القديم.

• مدرس الآثار المصرية القديمة بكلية الآداب - جامعة دمنهور. ayman_arch@yahoo.com 